Darwin embraced challenges to his theory of evolution by natural selection. Witness his stunning research into the construction of honeycomb by honeybees. Along with close observation, Darwin harnessed complex mathematics, comparative biology and collaboration with naturalist William Tegetmeier. In an ingenious experimental twist suggested by Tegetmeier, the bees were provided with red-tinted wax to reveal the building process. Thus Darwin demonstrated that honeybees
"Darwin frequently deployed the crowdsourced citizen science of his day." pivot on a point to create a cylindrical chamber, then rework it to incorporate the dead space. The result is a hexagon made "from a few very simple instincts".

Darwin also frequently deployed the crowdsourced citizen science of his day. He invited the public to send in observations of rare events. He had a hunch, for instance, that insects (and probably bees) must occasionally visit the bee orchid Ophrys apifera, and asked readers of the Gardener's Chronicle for evidence of insect pollination in this species. Although that enquiry drew a blank, he was right. In England, self-pollination is the flower's main mode of reproduction; in Mediterranean populations, bees occasionally facilitate crosses between different plants.

Today, as Costa reminds us, the incorporation of careful controls, large sample sizes, replication and statistical analysis have improved the rigour of experimental design and the robustness of conclusions. He also describes how today's scientists are using methods such as isotope analysis and DNA sequencing to add weight to Darwin's conclusions beyond his wildest imaginings. Darwin's Backyard drives home how science is a cumulative, constantly evolving endeavour.

All of this makes Darwin's experimental world a wonderful teaching tool, especially given that many of his trials lend themselves to replication. Fortunately, each chapter closes with Darwin-inspired experiments to try at home. Costa more than achieves his stated goals of revealing the evolution of Darwin's insights and the relevance of his methods now. As for me, I've dragged my "Darwin at Home" folder into another called "Backburner".

Henry Nicholls is a journalist based in London. His next book, Sleepyhead: Neuroscience, Narcolepsy and the Search for a Good Night, will be published in 2018.

e-mail:henry@henrynicholls.com

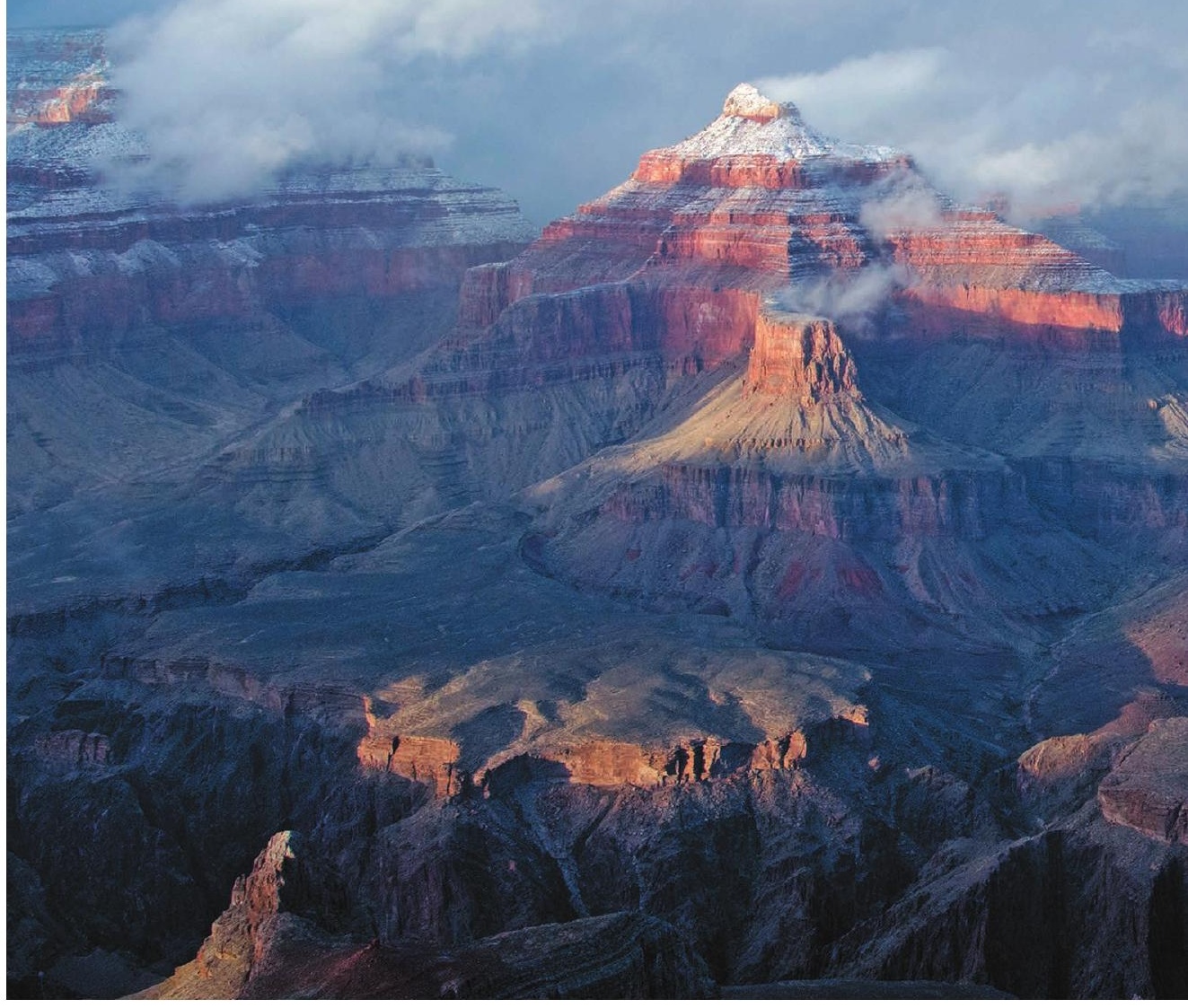

CONSERVATION

\title{
The great US land grab
}

\section{Kierán Suckling extols a study of looming threats to the country's publicly owned territory.}

$\mathrm{I}$ n Grand Canyon for Sale, environmental journalist Stephen Nash delivers a nuanced, comprehensive, surprisingly up-to-date review of the threats facing the United States' 2.5 million square kilometres of publicly owned land. That includes national parks, forests, deserts and wildlife refuges - sites Nash calls " 28 percent of the national dirt". Here are direct, captivating stories centring on efforts to protect Native American culture, endangered species and ecosystems; the actions of rangers and armed militias; the aims of US President Donald Trump's administration; and, always, politics and money.

Although relevant to all US public lands, and many elsewhere, the book focuses on the almost 23,000 square kilometres of public land centred on Arizona's Grand Canyon. Its subtitle, "Public Lands Versus Private Interests in the Era of Climate Change", is apt, but the last phrase is extraneous.

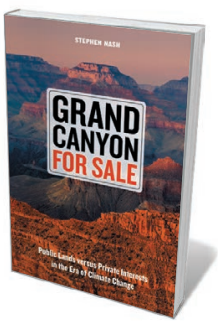

Grand Canyon for Sale: Public Lands Versus Private

Interests in the Era of Climate Change STEPHEN NASH University of California Press: 2017.
The implications of climate change for science and land management are covered well here, but are not the overarching theme. This is a strength. Climate change too often dominates conservation discussions, and can obscure the massive, pervasive and immediately actionable effects of habitat destruction and cultural disruption.

Grand Canyon for Sale is fundamentally about the use of power politics to hijack public values, heritage and acreage for private gain.

Nash's discussion of invasive species is 


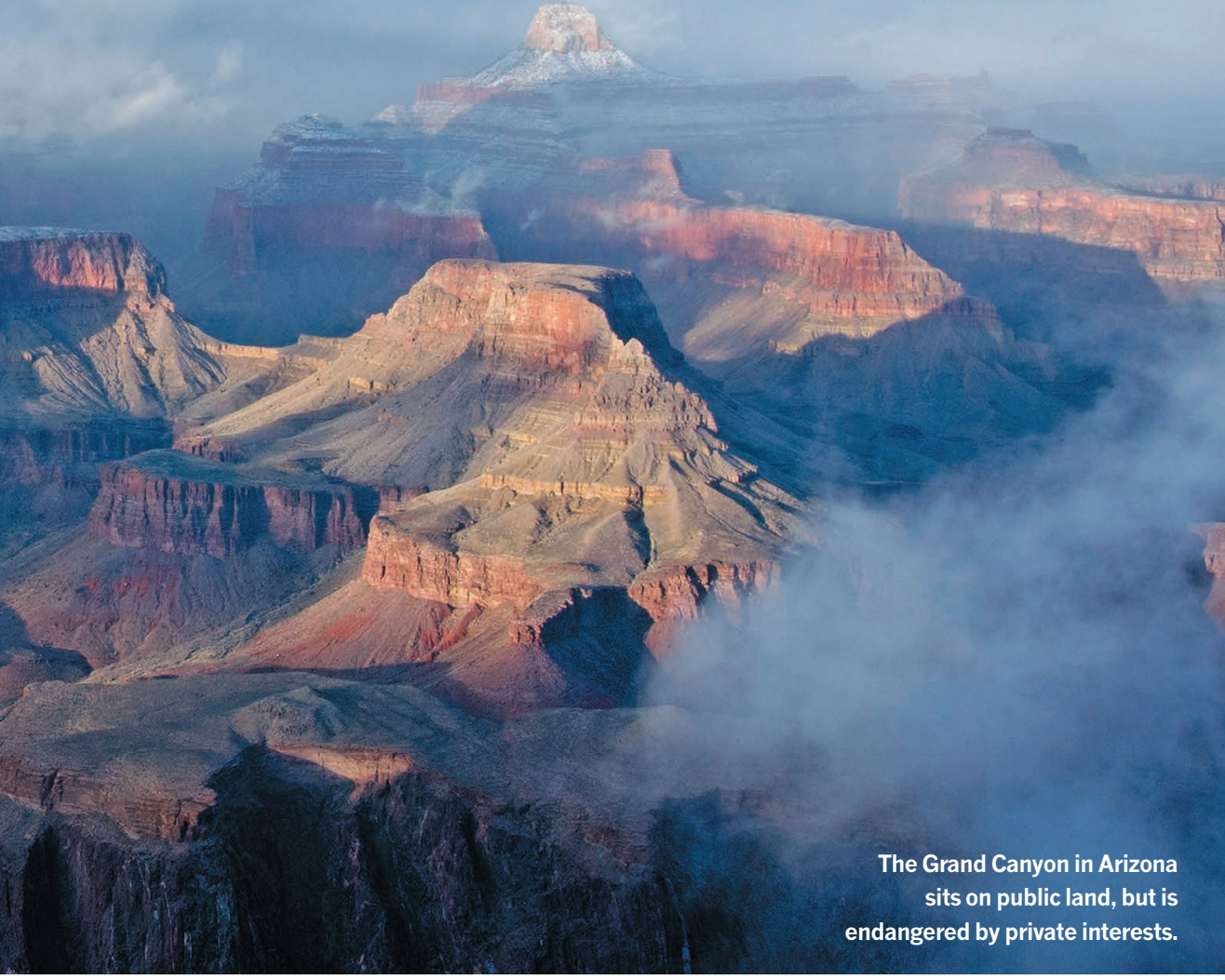

o. refreshing. Nationally, around 50,000 nonกิ native plants have been introduced to the United States, most in the past 70 years. About $10 \%$ of them are 'invasive': having naturalized and spread, they are harming native species, agriculture or human health. The Grand Canyon is remote, yet hosts some 200 non-native plants. Comprising $10 \%$ of its flora, these have an impact on $50 \%$ of its lands. Canyons once lush with grasses, forbs, cattails, willows and other wetland or riverside species have become monotonous expanses of Eurasian tamarisk trees.

The book shines in its attention to the corrosive influence of money and politics on land management. Most popular books on nature conservation treat the explosion of invasive species as tragic; a few argue it is beneficial; and almost all present it as an inadvertent by-product of globalization. Digging deeper into policy, law, funding and on-the-ground management, Nash finds that much of the problem is not inevitable. The Animal and Plant Health Inspection Service, the US agency charged with controlling the influx of exotics, has been captured and hobbled by the industries it is supposed to regulate. A retired federal inspector interviewed by Nash notes: "It happens all the time. Industry is going to push back." The vast majority of funding for

the control of invasives - US $\$ 2.3$ billion federally in 2016 - is spent on commercial agricultural and livestock interests. Very little goes to protect endangered species or the integrity of public-land ecosystems. Trump's proposed 2017 budget exacerbates the problem by slashing the Environmental Protection Agency's invasive-species funding while retaining that of the Department of Agriculture.

Nash's systematic, real-world approach is more enlightening than that of some recent anecdotal books, which reduce the messiness of reality to one-dimensional conceptual narratives. In my view, these mislead. For example, Emma Marris's Ram-

"The book shines in its attention to the corrosive influence of money and politics on land management." bunctious Garden (Bloomsbury, 2011) and Fred Pearce's The New Wild (Icon, 2015) paint a picture of a world in which conservationists are leading a heavily funded war against all exotic species. This group, we're told, is driven by a flawed concept of 'capital N' Nature that demands the restoration of ecosystems to a mythical pre-human state, and a conflict with exotic species that mirrors nationalistic sentiments. Yet not only is the majority of funding for invasives control directed at aiding commercial interests; in that capacity, it is used to protect non-native species from other non-natives, rather than to safeguard domestic species. These books also gloss over the fact that most exotic and invasive species are allowed to run their course, even in protected areas. There are, for example, 189 exotic plant species in Grand Canyon National Park, 82 of which are invasive. Yet park officials attempted to control just 1 of these in 1990; 5 in 1995; and 28 "particularly aggressive species" in 2009. In most cases, its plan is to contain or reduce, rather than eliminate.

Grand Canyon for Sale offers a more accurate account because Nash is willing to swim in the murky, inconsistent, contextdetermined realm of real-world decisionmaking. People here are driven by the mundane, not by high concepts. There is little time for purity, and less for war. Public-land managers are mostly scraping by, relying on volunteers and attempting to limit the spread of the most damaging invasives, especially those that prevent the recovery of endangered species. Sometimes, they even introduce new non-native species to control invasives.

The \$120-billion annual burden from invasive species is borne by the general public and government, while financial benefit accrues to private corporations. Noting that, Nash proposes a tax of one-tenth of a per cent on imports, which would provide $\$ 2.3$ billion per year to fund a radically improved programme of inspection and prevention.

Nash explores in equal depth the environmental impacts, politics and economics of livestock grazing, leapfrog development (including the battle over a proposal to build 2,200 houses, a hotel and a shopping centre at Tusayan, on the park edge) and looting of archaeological sites. He reviews the history of National Monument designations, created to protect public lands from resource extraction, and the Trump administration's efforts to undo many of them. And he follows the saga of the Bundy family, whose opposition to federal land protection has extended to mounting an assault by armed militia in Nevada and taking over Oregon's Malheur National Wildlife Refuge.

Nash makes clear that although scientists and land managers can provide essential information, ultimately, science is not power. Mobilized public opinion is power, and only power can save public lands from being destroyed for private profit.

Kierán Suckling is executive director of the Center for Biological Diversity, an international conservation group based in Tucson, Arizona. e-mail:ksuckling@biologicaldiversity.org 